\title{
Modelling to determine key drivers of water quality off sugarcane paddocks in the Great Barrier Reef catchment
}

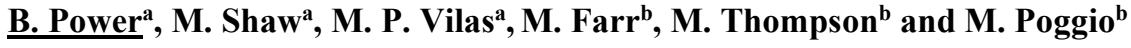 \\ ${ }^{a}$ Department of Resources, Queensland Government, Australia \\ ${ }^{b}$ Department of Agriculture and Fisheries, Queensland Government, Australia \\ Email: brendan.power@resource.qld.gov.au
}

\begin{abstract}
Reducing pollutants, such as nitrogen and sediment from sugarcane lands, in the Great Barrier Reef catchment is important for protecting the resilience of the World Heritage listed ecosystem. Modelling is used to predict the change in water quality in response to typical changes in sugarcane management. To accomplish this, workshops were conducted with groups of 15 to 20 industry experts in each of the major sugarcane growing regions and a range of typical agronomic management, appropriate for each region, was elicited. APSIM was used to simulate a farm in each of the three regions Burdekin Delta, Mackay, and Tully, to estimate the expected pollutant loads from each farm. Each in silico farm is represented by a combination of soil, climate and the range of management derived from the workshops. Simulated pollutants include erosion and dissolved inorganic nitrogen (DIN), from both leaching below the root zone and in runoff. To quantify and rank the effect of changes in management on pollutants exiting farms least squared regressions were estimated using model output. Results are presented for the key management of nutrient and irrigation rates, tillage, and fallow crop scenarios. We found the rate of applied mill mud had the greatest effect on DIN exiting sugarcane paddocks both via leaching and in runoff (Figure 1) and the amount of tillage had the greatest effect on erosion (Figure 2).
\end{abstract}

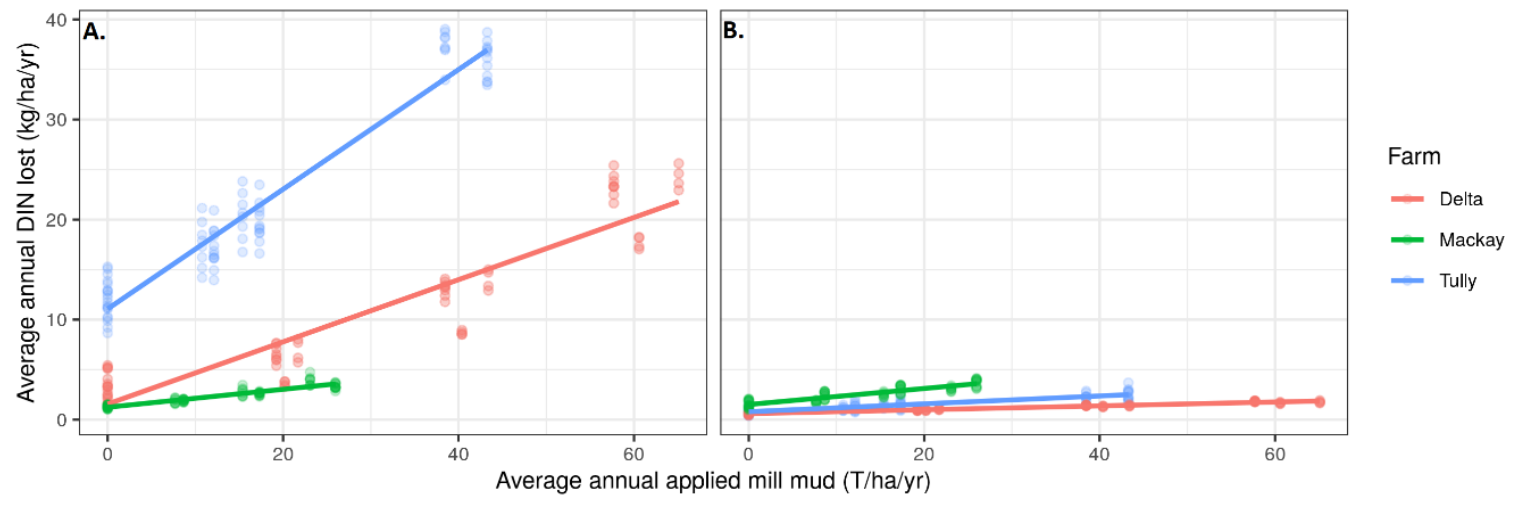

Figure 1. Simulated average annual leached DIN (A) and DIN in runoff (B) by average annual applied mill mud for a subset of management and a typical farm in each region (colour).

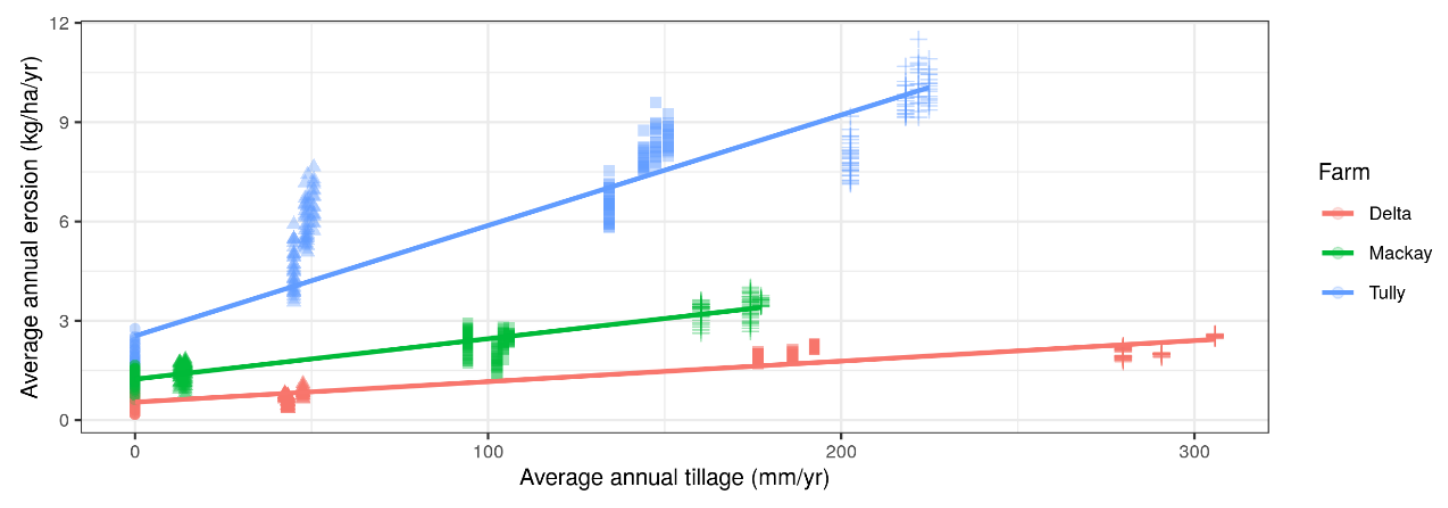

Figure 2. Average annual erosion $(\mathrm{T} / \mathrm{ha} / \mathrm{yr})$ by tillage $(\mathrm{mm} / \mathrm{yr})$. Point shape indicates different tillage scenarios.

Keywords: Water quality, APSIM, fertiliser, tillage, dissolved inorganic nitrogen 
Power et al., Modelling to determine key drivers of water quality off sugarcane paddocks in the Great Barrier Reef catchment

\section{INTRODUCTION}

Sugarcane production in Queensland occurs, for the most part, in areas with relatively high annual rainfall or applied irrigation and on coastal flood plains within the catchment of the Great Barrier Reef World Heritage Area (GBR). This means there is little resistance to off-paddock pollutants making it into the GBR lagoon and is a contributing factor to sugarcane areas being the largest contributors of dissolved inorganic nitrogen (DIN) into the GBR lagoon (Waterhouse et al., 2017). The Australian and Queensland Governments have codeveloped several programs, such as the Reef 2050 Water Quality Improvement Plan (Commonwealth of Australia, 2020) and the Reef Rescue program (www.reefrescueresearch.com.au) with the purpose of improving water quality flowing into the GBR. In this study we demonstrate the use of modelling to provide an estimate of pollutants exiting sugarcane paddocks in each of the main regions for the range of typical sugarcane management. Data obtained from workshops with sugarcane production experts were used to parameterise simulations of sugarcane farming systems. Simulations were validated using relevant regional reported mill yields. Simulated responses in pollutants, DIN and erosion, exiting sugarcane paddocks over the range of existing agronomic management are ranked and the largest responses presented.

\section{SUGARCANE FARMS}

The sugarcane regions with the largest concentration of sugarcane production in the GBR catchment, and hence the focus of this study, are the Wet Tropics $\left(1,800 \mathrm{~km}^{2}\right)$, Mackay Whitsunday $\left(1,677 \mathrm{~km}^{2}\right)$, and the Lower Burdekin $\left(1,048 \mathrm{~km}^{2}\right)$. A representative farm, which is defined by a unique soil type, climate and set of possible agronomic management, was modelled for each of these sugarcane regions. These are 'average' or typical farms in each region and do not map directly to physical farms. For each representative farm, Table 1 lists the soil types and corresponding references, paddock slopes and climate summary statistics. Historical climate data for each farm was sourced from www.longpaddock.qld.gov.au/silo (Jeffrey et al. 2001). To determine the range of typical management to be modelled in each region multiple workshops were conducted with industry experts which consisted of local consultant agronomists and irrigation consultants, sugarcane farming system experts from the Queensland Department of Agriculture (DAF), Natural Resource Management (NRM) groups, and sugarcane industry representatives such as Canegrowers, Sugar Research Australia, and local productivity services.

Table 1. Representative sugarcane farm parameters.

$\begin{array}{ccccccc}\text { Farm } & \begin{array}{c}\text { Sugarcane } \\ \text { region }\end{array} & \text { Soil } & \begin{array}{c}\text { Soil } \\ \text { reference }\end{array} & \begin{array}{c}\text { Slope } \\ (\mathbf{\%})\end{array} & \begin{array}{c}\text { Mean } \\ \text { annual } \\ \text { rainfall } \\ (\mathbf{m m})\end{array} & \begin{array}{c}\text { Mean } \\ \text { annual daily } \\ \text { temp. range } \\ \left({ }^{\circ} \mathbf{C}\right)\end{array} \\ \text { Tully } & \text { Wet Tropics } & \text { Brown Dermosol } & \begin{array}{c}\text { Cannon et } \\ \text { al. }(1992)\end{array} & 0.2 & 3,270 & 19.5-28.9 \\ \text { Delta } & \begin{array}{c}\text { Lower } \\ \text { Burdekin }\end{array} & \begin{array}{c}\text { Dermosol (structured } \\ \text { clay or clay loam) }\end{array} & \begin{array}{c}\text { Cannon et } \\ \text { al. }(1992)\end{array} & 0.05 & 795 & 18.2-29.3 \\ \text { Mackay } & \begin{array}{c}\text { Mackay } \\ \text { Whitsunday }\end{array} & \begin{array}{c}\text { Chromosol or heavy } \\ \text { clay loam }\end{array} & \begin{array}{c}\text { Masters et } \\ \text { al. }(2008)\end{array} & 0.2 & 1,330 & 17.8-28.4\end{array}$

The sugarcane cropping system consists of a plant crop which is harvested after about 13-15 months. It is then allowed to re-grow (ratoon) 3 or 4 times. This is then followed by a fallow period which may include a sown crop. Table 2 lists the number of ratoon crops, sow dates, nutrient rates, fallow crops, and trash management that were chosen, in consultation with the expert working groups, as typical for each region. Crop nutrients can be combinations of inorganic mineral nitrogen $(\mathrm{N})$ fertiliser and mill mud which is a sugar mill by-product that consists of fibre, soil, and other milling process residuals. When $\mathrm{N}$ is applied in combination with mill mud or a legume fallow crop its application rate is often reduced, but not always, to account for the additional nitrogen from the other sources. Sugar Research Australia provides recommendations for the amount to discount $\mathrm{N}$ rates in the Six Easy Steps Toolbox (https://sugarresearch.com.au/growers-and-millers/nutrient-management/sixeasy-steps-toolbox/).

During the fallow many strategies for land preparation exist. These range from zero-tillage to full cultivation which includes, for example, many passes with a disc ploughs, deep ripping, and rotary ploughs. For simplicity four tillage strategies in increasing level of soil disturbance were modelled. Similarly, there are many possible 
Power et al., Modelling to determine key drivers of water quality off sugarcane paddocks in the Great Barrier Reef catchment

options for fallow crop management but for simplicity only three were chosen: no fallow crop; a typical legume crop for each region (listed in Table 1) which is grown for either cover, where it is killed with a herbicide application or ploughed out at flowering; or a legume crop that is grown to maturity and harvested.

Table 2. Assumed typical sugarcane agronomic management practices for each region.

\begin{tabular}{|c|c|c|c|c|c|c|c|}
\hline $\begin{array}{l}\text { Sugarcane } \\
\text { region }\end{array}$ & Farm & $\begin{array}{l}\text { Number } \\
\text { of } \\
\text { ratoons }\end{array}$ & $\begin{array}{l}\text { Sow } \\
\text { Dates }\end{array}$ & $\begin{array}{l}\text { Plant and } \\
\text { ratoon crop } \\
\mathrm{N} \text { rates } \\
(\mathrm{kg} / \mathrm{ha})\end{array}$ & $\begin{array}{l}\text { Mill mud } \\
\text { rate }(T / h a)\end{array}$ & $\begin{array}{l}\text { Fallow } \\
\text { crop }\end{array}$ & $\begin{array}{l}\text { Trash } \\
\text { management }\end{array}$ \\
\hline Wet tropics & Tully & 4 & Jul & $105-180$ & $0-250$ & cowpea & GCTB* \\
\hline $\begin{array}{l}\text { Mackay } \\
\text { Whitsunday }\end{array}$ & Mackay & 4 & May & $100-180$ & $0-150$ & soybean & GCTB* \\
\hline $\begin{array}{l}\text { Lower } \\
\text { Burdekin }\end{array}$ & Delta & 3 & Apr & $145-240$ & $0-150$ & mungbean & Burnt \\
\hline
\end{tabular}

cane trash blanketing (GCTB)

Water for irrigation is available in significant amounts in the Lower Burdekin and Mackay. For Mackay, irrigation is usually only available as a supplement to rainfall and, therefore, has limited variability in irrigation management. For this reason, a typical allocation of $120 \mathrm{~mm} /$ year was implemented and irrigation events triggered when soil water falls below $40 \%$ of a full profile was assumed in consultation with the Mackay expert working group. The Lower Burdekin is split into two regions based on management of irrigation infrastructure and allocation or entitlement of water, the Burdekin Haughton Water Supply Scheme (BHWSS) and the Lower Burdekin Water Northern and Southern Divisions (Delta). This, in combination with different soils, has resulted in different amounts of sugarcane harvested per unit of applied irrigation i.e., crop water use efficiency (CWUE). In consultation with the Burdekin expert working group these difference between irrigation regions result in different CWUE's. BHWSS farms typically have CWUE ranging from 4.5 to $8.5 \mathrm{t} / \mathrm{ha} / \mathrm{ML}$ and the Delta farms typically have a CWUE ranging from 3.5 to $7.5 \mathrm{t} / \mathrm{ha} / \mathrm{ML}$.

\section{BIOPHYSICAL MODEL}

Farms were modelled using the Agricultural Production System sIMulator (APSIM) (www.apsim.info; Holzworth et al. 2014) Version 7.10. It is a point scale process based daily time step simulation model used to predict economic and ecological outcomes by simulating the biophysical processes and interactions between soil, climate, crop genotype, and agronomic management (e.g., tillage, fertiliser, or irrigation rates). APSIM calculates crop yield as biomass accumulated via conversion of intercepted radiation, subject to a lack of stress due to temperature extremes, insufficient soil water or N. The daily soil nitrogen and water cycle is modelled by APSIM's SOILN and SOILWAT modules, respectively (Probert et al., 1997). APSIM simulates loss of surplus soil water in drainage and runoff and loss of surplus soil $\mathrm{N}$ as leaching. Surplus soil $\mathrm{N}$ lost in runoff is simulated with the inclusion of an additional $\mathrm{N}$ in runoff model that was calibrated to 10 years of locally relevant field observational data (Vilas et al., 2021). Soil sediment in runoff is simulated using the Freebairn sub-model in APSIM's erosion module (Littleboy et al. 1992, Freebairn and Wockner 1986).

Changes to APSIM's standard release sugarcane model (Keating et al., 1999) include reductions in radiation use efficiency for the tropical environments of Tully and Mackay farms (Dias et al., 2019) and the effect of storms on crop lodging following Inman-Bamber et al. (2004). Mill mud is applied in APSIM as surface organic matter with a chemical composition taken from Thorburn et al. (2008) and set at 23.1 and $31.7 \mathrm{NH}_{4}$ and $\mathrm{NO}_{3}$ ppm respectively. Composition was assumed to be constant across all regions but varies, with within mill variability as great as between mill variability (Bloesch and Barry, 2010).

A sample of the implementation in APSIM of the different tillage events is detailed in Table 3 which shows the percent of surface organic matter incorporated and the depth of incorporation. Tillage events cause an increase in surface roughness and, hence, reduction in runoff potential. This is modelled via modification of the curve numbers (Soil Conservation Service, 1972) and occurs until the amount of cumulative rainfall linearly decreases the roughness and the effect is removed. 
Power et al., Modelling to determine key drivers of water quality off sugarcane paddocks in the Great Barrier Reef catchment

Table 3. Model parameters for a sample of tillage types.

\begin{tabular}{|c|c|c|c|c|}
\hline Tillage type & $\begin{array}{c}\text { Percent } \\
\text { incorporation }\end{array}$ & $\begin{array}{l}\text { Incorporation } \\
\text { depth }(\mathrm{mm})\end{array}$ & $\begin{array}{l}\text { Curve } \\
\text { number } \\
\text { reduction }\end{array}$ & $\begin{array}{c}\text { Cumulative } \\
\text { rain to } \\
\text { cease effect }\end{array}$ \\
\hline centrebust & 0.1 & 250 & 12.5 & 400 \\
\hline convplant & 0.1 & 175 & 10 & 200 \\
\hline cutaway & 0.1 & 50 & 2.5 & 50 \\
\hline ddop & 0 & 0 & 5 & 5 \\
\hline disc & 0.6 & 150 & 12.5 & 400 \\
\hline discoffset & 0.85 & 250 & 7.5 & 400 \\
\hline hillup & 0.9 & 100 & 7.5 & 100 \\
\hline moundplant & 0.9 & 200 & 10 & 200 \\
\hline multiweeder & 0.5 & 100 & 5 & 50 \\
\hline plough & 0.9 & 300 & 15 & 500 \\
\hline rip & 0.15 & 300 & 20 & 500 \\
\hline rotary & 0.9 & 150 & 7.5 & 200 \\
\hline rotarylight & 0.45 & 100 & 5 & 300 \\
\hline sbharrow & 0 & 50 & 2.5 & 100 \\
\hline semihillup & 0.9 & 100 & 7.5 & 100 \\
\hline shallowcultivation & 0.5 & 150 & 7.5 & 200 \\
\hline trashinc & 0.85 & 250 & 10 & 200 \\
\hline Wavydisc & 0 & 75 & 3.75 & 0 \\
\hline zonal & 0.5 & 75 & 12.5 & 200 \\
\hline
\end{tabular}

\section{MODEL VALIDATION}

APSIM was parameterised using different combinations of nutrient rates (mineral inorganic $\mathrm{N}$ and mill mud), with and without discounted $\mathrm{N}$ rates, tillage scenarios, fallow management, irrigation management (Delta farm only) and rotation start year and run using historical climate data from 1960 to present. This resulted in 5760 different simulations for the three farms for Tully, Mackay and Delta. For the purpose of validation, the distribution of simulated yields resulting from the range of management is compared to the average regional reported yields obtained from the QCANESelect website (Sugar Research Australia, 2020) for years 1990 to 2019. Yields were used for validation because they are an integrator of the soil water and nitrogen cycles, management, and climate on the cropping system. As stated, the simulated farms are 'average' farms that do not map directly to actual farms and hence no observational data exists at the farm scale and hence validation with regional average yields is a pragmatic alternative. Figure 3 shows the distribution of simulated sugarcane yields (t/ha) resulting from all management combinations, as box and whiskers, and the average regional reported yields to the relevant local mills as red points.

The simulations of each farm have just one soil and climate, yet the observed yields are averages of all farms with differing soil, climate and management delivering to a mill, it is reasonable to expect significant differences between the two. Even so, the observed yields are, for the most part, in the range of simulated yields for all years and farms and hence, we are confident the biological model adequately represented a plausible example of a farming systems in each of the three sugarcane regions. 
Power et al., Modelling to determine key drivers of water quality off sugarcane paddocks in the Great Barrier Reef catchment

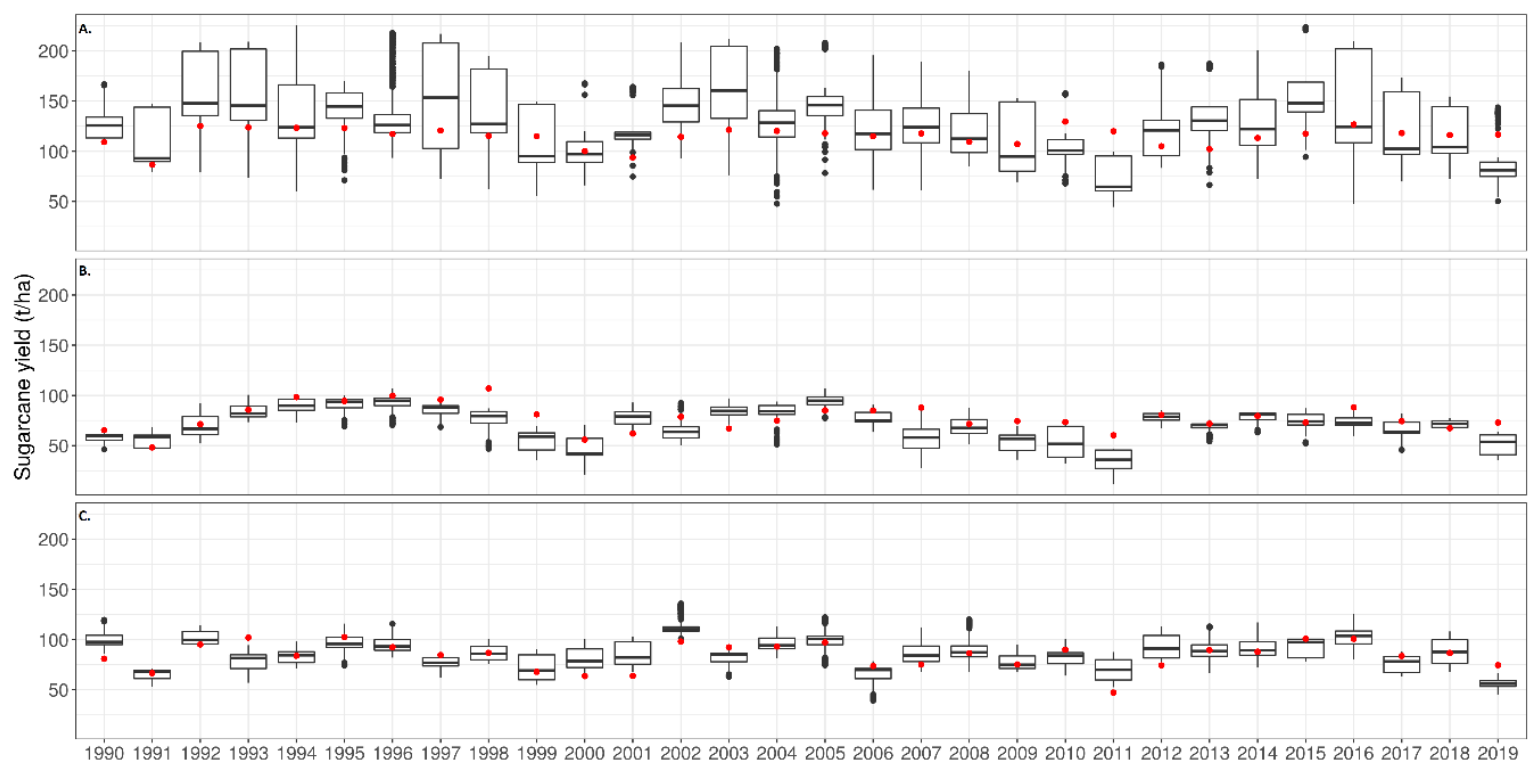

Figure 3. Distributions of simulated sugarcane yields (box and whiskers) for Delta, Mackay and Tully farm (plots A to C respectively) and the average regional mill reported yields (red points).

\section{POLLUTANT RESPONSE TO MANAGEMENT}

To determine the expected change in pollutants due to change in management of the sugarcane paddocks least squared regressions were estimated on the average annual output for each combination of pollutant, management and farm. The coefficient estimates from these regressions are listed in Table 4. The slope represents the expected change in annual pollutant from a unit change in corresponding management over the range of management considered typical for each region. Results are presented in order of greatest response to least within each farm and pollutant group. Regressions of other management responses, such as fallow crop scenario, and their interactions, were estimated but results were negligible and hence omitted. To determine an erosion response the four categorical tillage scenarios were converted to a continuous numeric tillage metric $(\mathrm{mm} / \mathrm{yr})$. This was done by calculating the average annual total of percent surface matter incorporated by depth (see examples in Table 3) for all tillage events.

Table 4. Estimated regressions coefficients for pollutant by management.

\begin{tabular}{|c|c|c|c|c|}
\hline Farm & $\begin{array}{l}\text { Average annual } \\
\text { Pollutant }\end{array}$ & $\begin{array}{c}\text { Management (average annual } \\
\text { applied) }\end{array}$ & Intercept & Slope \\
\hline \multirow[t]{8}{*}{ Delta } & DIN in runoff $(\mathrm{kg} / \mathrm{ha} / \mathrm{yr})$ & Mill mud (t/ha/yr) & $1.14 \mathrm{E}+00$ & $3.13 \mathrm{E}-02$ \\
\hline & & Mineral N fertiliser ( $\mathrm{kg} / \mathrm{ha} / \mathrm{yr})$ & $1.73 \mathrm{E}+00$ & $3.21 \mathrm{E}-03$ \\
\hline & & Irrigation (mm/ha/yr) & $-2.06 E+00$ & $2.96 \mathrm{E}-03$ \\
\hline & DIN leached (kg/ha/yr) & Mill mud (t/ha/yr) & $4.77 E+00$ & $3.11 \mathrm{E}-01$ \\
\hline & & Mineral $\mathrm{N}$ fertiliser ( $\mathrm{kg} / \mathrm{ha} / \mathrm{yr})$ & $7.95 \mathrm{E}+00$ & $5.27 \mathrm{E}-02$ \\
\hline & & Irrigation (mm/ha/yr) & $-8.56 \mathrm{E}+00$ & $1.64 \mathrm{E}-02$ \\
\hline & Erosion (T/ha/yr) & Tillage $(\mathrm{mm} / \mathrm{yr})$ & $1.45 \mathrm{E}+00$ & $3.73 \mathrm{E}-03$ \\
\hline & & Irrigation & $-1.14 \mathrm{E}+00$ & $2.32 \mathrm{E}-03$ \\
\hline \multirow[t]{5}{*}{ Mackay } & DIN in runoff $(\mathrm{kg} / \mathrm{ha} / \mathrm{yr})$ & Mill mud (t/ha/yr) & $2.14 E+00$ & 7.57E-02 \\
\hline & & Mineral $\mathrm{N}$ fertiliser ( $\mathrm{kg} / \mathrm{ha} / \mathrm{yr})$ & $1.75 \mathrm{E}+00$ & $1.40 \mathrm{E}-02$ \\
\hline & DIN leached (kg/ha/yr) & Mill mud (t/ha/yr) & $2.32 E+00$ & $1.03 \mathrm{E}-01$ \\
\hline & & Mineral $\mathrm{N}$ fertiliser $(\mathrm{kg} / \mathrm{ha} / \mathrm{yr})$ & 8.00E-01 & $2.94 \mathrm{E}-02$ \\
\hline & Erosion (t/ha/yr) & Tillage $(\mathrm{mm} / \mathrm{yr})$ & $1.28 \mathrm{E}+00$ & $1.10 \mathrm{E}-02$ \\
\hline \multirow[t]{3}{*}{ Tully } & DIN in runoff $(\mathrm{kg} / \mathrm{ha} / \mathrm{yr})$ & Mill mud (t/ha/yr) & 8.59E-01 & $4.01 \mathrm{E}-02$ \\
\hline & & Mineral $\mathrm{N}$ fertiliser ( $\mathrm{kg} / \mathrm{ha} / \mathrm{yr})$ & $1.01 \mathrm{E}-01$ & $1.40 \mathrm{E}-02$ \\
\hline & DIN leached (kg/ha/yr) & Mill mud (t/ha/yr) & $1.21 \mathrm{E}+01$ & $6.00 \mathrm{E}-01$ \\
\hline
\end{tabular}


Power et al., Modelling to determine key drivers of water quality off sugarcane paddocks in the Great Barrier Reef catchment

$\begin{array}{cccc} & \text { Mineral N fertiliser }(\mathrm{kg} / \mathrm{ha} / \mathrm{yr}) & -1.58 \mathrm{E}+00 & 2.33 \mathrm{E}-01 \\ \text { Erosion }(\mathrm{t} / \mathrm{ha} / \mathrm{yr}) & \text { Tillage }(\mathrm{mm} / \mathrm{yr}) & 2.28 \mathrm{E}+00 & 3.01 \mathrm{E}-02\end{array}$

Figures 1 (see Abstract) and 4 show the expected response in DIN lost via leaching and runoff due to changes in organic mill mud and mineral $\mathrm{N}$ fertiliser, respectively. Leaching, as opposed to runoff, is the greater loss pathway for DIN and changes in mill mud rates causes the greatest change in DIN losses, both leached and in runoff, for the three farms modelled. The disconnect in $\mathrm{N}$ and mill mud rates reported in Table $2(\mathrm{~kg} / \mathrm{ha} / \mathrm{crop})$ and the amounts shown on the horizontal axis in Figure 1 and 2 is due to the use of average applied annual fertiliser $(\mathrm{kg} / \mathrm{ha} / \mathrm{yr})$ which includes the effect of different ratoon numbers on cropping intensity. Whereas rates listed in Table 2 are applied fertiliser rates per crop class ( $\mathrm{kg} / \mathrm{ha} / \mathrm{crop})$ and hence do not account for the fallow year when no fertiliser is applied. The Delta farm has a fallow once every 5 years compared to the Mackay and Tully farm which fallow once every 6 years. Figure 2 (see Abstract) shows the change in erosion ( $t /$ ha) due to changes in tillage and different point shapes show the tillage scenarios. Figure 5 shows the expected response in DIN lost via leaching (A) and runoff(B) due to changes in applied irrigation for a farm in the Lower Burdekin (Delta).

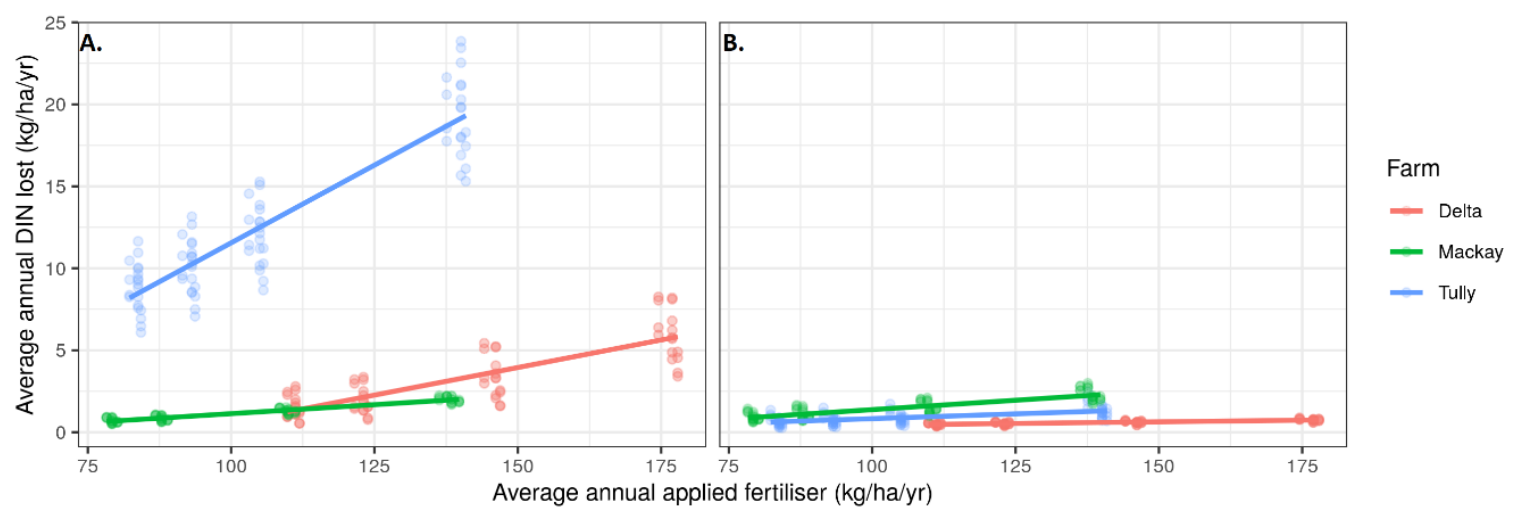

Figure 4. Simulated average annual leached DIN (A) and DIN in runoff (B) by average annual applied mineral inorganic fertiliser for a subset of management and a typical farm in each region (colour).

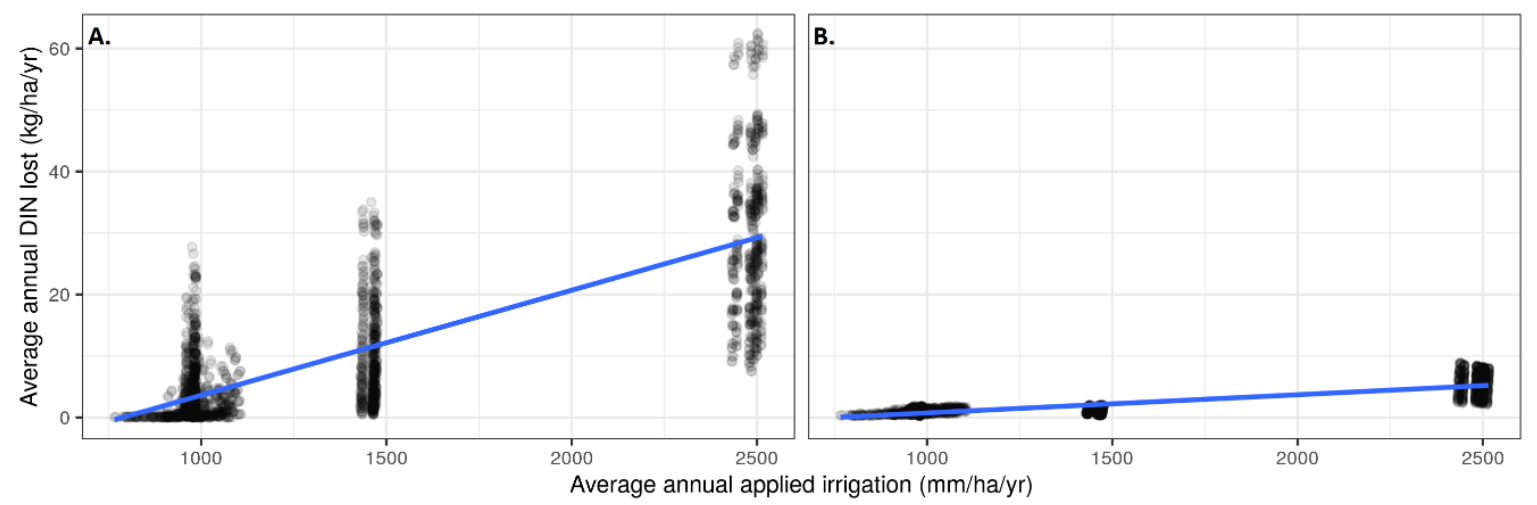

Figure 5. Simulated average annual leached DIN (A) and DIN in runoff (B) by average annual applied irrigation for a subset of management and a typical farm (Delta) in the Lower Burdekin.

\section{CONCLUSION}

We showed that a process-based farming system simulation model, such as APSIM, is effective in identifying changes in water quality due to changes in agronomic management of sugarcane paddocks. Typical farms from each region were simulated and, due to different soils, climate and a range of typical management, differences in responses are presented. The results, however, should not be extrapolated beyond the individual farms and management modelled here to draw conclusions about the sugarcane industries in the three regions. 
Power et al., Modelling to determine key drivers of water quality off sugarcane paddocks in the Great Barrier Reef catchment

can be parameterised to predict the expected response in the pollutants DIN and sediment exiting sugarcane paddocks resulting from changes in agronomic management.

\section{ACKNOWLEDGMENTS}

We wish to acknowledge the funding support from the Australian and Queensland governments. We thank Mark Silburn, Jacqueline Wirth, and two anonymous reviewers for their valuable comments.

\section{REFERENCES}

Bloesch PM, Barry G (2010) 'Mill Mud/Ash Research in Queensland: A Review.' Unpublished Technical Report, Science Delivery, Department of Science, Information Technology, Innovation and the Arts.

Cannon, M. G., Smith, C. D., \& Murtha, G. G., 1992. Soils of the Cardwell-Tully area, North Queensland. Division of Soils Divisional Report, No. 115.

Commonwealth of Australia, 2020. Reef 2050 Integrated Monitoring and Reporting Program annual business plan 2020-2021. Townsville

Dias, H. B., Inman-Bamber, G., Bermejo, R., Sentelhas, P. C., \& Christodoulou, D., 2019. New APSIM-Sugar features and parameters required to account for high sugarcane yields in tropical environments. Field Crops Research, 235, 38-53.

Freebairn, D. M., \& Wockner, G. H., 1986. A study of soil erosion on Vertisols of the eastern Darling Downs, Queensland. I. Effects of surface conditions on soil movement within contour bay catchments. Soil Research, 24(2), 135-158.

Inman-Bamber, N. G., Attard, S. J., \& Spillman, M. F., 2004. Can lodging be controlled through irrigation?. In 2004 Conference of the Australian Society of Sugar Cane Technologists held at Brisbane, Queensland, Australia, 4-7 May 2004 (pp. 1-11). PK Editorial Services Pty Ltd.

Holzworth, D. P., Huth, N. I., deVoil, P. G., Zurcher, E. J., Herrmann, N. I., McLean, G., ... \& Keating, B. A., 2014. APSIM-evolution towards a new generation of agricultural systems simulation. Environmental Modelling \& Software, 62, 327-350.

Jeffrey, S.J., Carter, J.O., Moodie, K.B. and Beswick, A.R., 2001. Using spatial interpolation to construct a comprehensive archive of Australian climate data, Environmental Modelling and Software, Vol 16/4, pp 309-330. DOI: 10.1016/S1364-8152(01)00008-1

Keating, B. A., Robertson, M. J., Muchow, R. C., \& Huth, N. I., 1999. Modelling sugarcane production systems I. Development and performance of the sugarcane module. Field crops research, 61(3), 253-271.

Littleboy, M., Silburn, D. M., Freebairn, D. M., Woodruff, D. R., Hammer, G. L., \& Leslie, J. K., 1992. Impact of soil erosion on production in cropping systems. I. Development and validation of a simulation model. Soil Research, 30(5), 757-774.

Masters, B., Rohde, K., Gurner, N., Higham, W., \& Drewry, J., 2008. Sediment, nutrient and herbicide runoff from canefarming practices in the Mackay Whitsunday region: a field-based rainfall simulation study of management practices. Queensland Department of Natural Resources and Water for the Mackay Whitsunday Natural Resource Management Group, Australia.

Probert, M. E., Dimes, J. P., Keating, B. A., Dalal, R. C., \& Strong, W. M., 1998. APSIM's water and nitrogen modules and simulation of the dynamics of water and nitrogen in fallow systems. Agricultural systems, 56(1), 1-28.

Soil Conservation Service, 1972. National Engineering Handbook Section 4: Hydrology, Soil Conservation Service, USDA, Washington.

Sugar Research Australia, 2020. https://tools.sugarresearch.com.au/QCANESelect/Default.aspx

Thorburn, P. J., Park, S. E., Bloesch, P., Webster, A. J., Horan, H. L., Biggs, I. M., \& Biggs, J. S., 2008. Potential impacts of mill mud on nitrogen fertiliser requirements for sugarcane production. In Proceedings of the 2008 Conference of the Australian Society of Sugar Cane Technologists held at Townsville, Queensland, Australia, 29 April-2 May 2008 (pp. 367-368). Australian Society of Sugar Cane Technologists.

Vilas, M. P., Shaw, M., Rohde, K., Power, B., Donaldson, S., Foley, J., \& Silburn, M., 2021. Ten years of monitoring dissolved inorganic nitrogen in runoff from sugarcane informs development of a modelling algorithm to prioritise organic and inorganic nutrient management. Science of The Total Environment, 150019. doi: 10.1016/J.SCITOTENV.2021.150019

Waterhouse, J., Schaffelke, B., Bartley, R., Eberhard, R., Brodie, J., Star, M., Thorburn, P. J., Rolfe, J., Ronan, M., Taylor, B., \& Kroon, F., 2017. 2017 Scientific Consensus Statement: Land Use Impacts on Great Barrier Reef Water Quality and Ecosystem Condition. 2017 Scientific Consensus Statement: A Synthesis of the Science of Land-Based Water Quality Impacts on the Great Barrier Reef, 17. https:/www.reefplan.qld.gov.au/about/assets/2017-scientific-consensus-statement-summary.pdf 